\title{
Due to the Law of Notary That Compare Criminal Law Acts That Have Permanent Law Power and Their Implication on the Notary Protocol
}

\author{
Adhitia Rully Saputra; Elwi Danil; Beatrix Benni \\ Magister of Notary Program, Faculty of Law, Andalas University, Padang, Indonesia
}

http://dx.doi.org/10.18415/ijmmu.v8i10.3077

\begin{abstract}
Notaries as one of the legal professions are not immune from mistakes that will eventually lead to a notary profession in violating the UUJN-P and the Code of Ethics and some even have the potential for punishment. Given that the role and authority of a Notary is very important in social life, the behavior and actions of a Notary in carrying out the function of authority are vulnerable to abuse that can cause harm to the community. Notaries who act outside the authority that has been determined by law can be categorized as unlawful acts. As has been tried in the Class IA Padang District Court with Decision Number 27/Pid.Sus/TPK/2016/PN-Pdg. In this case, the Notary was accused of corruption in land acquisition for Campus III of the State Islamic Institute (IAIN) Imam Bonjol Padang (now UIN Imam Bonjol). The formulation of the problem in this study are: a). What are the legal consequences for a Notary who commits a criminal act that has permanent legal force? b). What are the implications of the Notary's dismissal on the Notary Protocol? The approach used in this research is empirical juridical. This study uses primary and secondary data. Data were analyzed qualitatively. The results of the study show that: 1) The Notary was dishonorably dismissed by the Minister because it was proven legally that he had committed a criminal act of corruption which had permanent legal force, but the implementation process took a long time because it was waiting for the Minister's decision on the dismissal of the Notary. 2). With the dismissal of a Notary who commits a criminal act that has permanent legal force, the Notary Protocol must be handed over to the Notary receiving the Protocol appointed by the Minister.
\end{abstract}

Keywords: Legal Consequences, Notary; Crime; Notary Protocol

\section{Introduction}

The Republic of Indonesia is a legal state where power is subject to law. ${ }^{1}$ The law regulates all relations between individuals or individuals with groups or communities as well as individuals with the government. The principle of state guarantees of certainty, what, and legal protection, which is based on truth and justice, and legal relations, whether public or civil, must be carried out based on the provisions of laws and regulations. ${ }^{2}$ Regulations are decisions of the will of one party who has power (the state) and authority, while the agreement is a reflection of the decision of the will of two or more parties who bind themselves, in other words that the agreement in the agreement is based on his own will, while the law is free from his will. because of coercion that must be obeyed. ${ }^{3}$

\footnotetext{
${ }^{1}$ Mochtar Kusumaatmadja, B. Arief Sidharta, Pengantar Ilmu Hukum Suatu Pengenalan Pertama Ruang Lingkup Berlakunya Ilmu Hukum Buku I, Bandung: Alumni, 2000, pg. 43

${ }^{2}$ Supriadi, Etika \& Tanggung Jawab Profesi Hukum di Indonesia, Jakarta, Sinar Grafika, 2008, pg. 29

${ }^{3}$ Herlien Budiono, 2014, Ajaran Umum Hukum Perjanjian dan Penerapannya di Bidang Kenotariatan, PT. Citra Aditya Bakti, Bandung, pg. 15
} 
Every individual has desires and interests related to other individuals, and each of these individuals wants, interests, and is protected. If there are many interests, there will be no conflict or clashes between human beings, because their interests are conflicting. Conflicts of interest that occur when in carrying out or pursuing interests, harm the interests of others. In shared life or society, conflict is unavoidable. In order for human interests to be protected, the law must be implemented. However, in practice, the law can run normally, orderly and effectively, but there can also be violations of the law ${ }^{4}$

Therefore, the position of a Notary is required by the rule of law with a view to assisting and serving the public who need authentic written evidence regarding legal circumstances, events or actions. The position of a notary is a position of trust where the public entrusts their legal actions to him, which in itself also carries a heavy responsibility for him. The presence of a Notary is to meet the needs of the community who require authentic legal documents (deeds) in the field of civil law, so that the Notary has the responsibility to serve the public in civil lawsuits, demanding compensation and interest costs if it turns out that the deed can be proven to be made not in accordance with the applicable legal rules. apply. This is a form of Notary accountability to the public.

The Notary Position Regulation aims to provide assurance to the public that a notary in carrying out his duties and positions is truly for the benefit of the community and as a public official who is responsible for making authentic deeds. The implementation of the duties and positions of a notary must be based on integrity, high honesty and impartiality. Notary in his profession aims to serve the community as an official appointed by the Government. In their service, Notaries are bound by UUJN-P and the Notary Code of Ethics. Notary Profession is a Noble Profession (nobile officium) because the Notary profession is very closely related to humanity.

In other cases, not a few notaries are also abusing their authority just to get bigger profits. As a public official who has the authority and expertise in the field of law, notaries take advantage of these advantages to commit acts against the law or criminal acts that harm the parties who use the services of the notary. As happened in Padang City, there was a notary person who committed a criminal act of corruption in land acquisition for Campus III State Islamic University (UIN) Padang in Sungai Bangek, Koto Tangah District, Padang City with an area of 60 hectares. There were several problems in the acquisition of the land, including fictitious land but it was paid for, the money was there but it was reduced from the actual price, and from 60 hectares of land that was certified only 40 hectares. Currently the notary has been sentenced to a criminal sentence based on the Padang District Court Decision No. 27/Pid.Sus-TPK/2016/PN Padang. With the proof that the Notary has committed a crime, where the criminal penalty is more than 5 (Five) Years, the Notary is dishonorably dismissed by the Minister as mandated in Article 13 of the UUJNP, namely: a court decision that has obtained permanent legal force due to committing a crime punishable by imprisonment of 5 (five) years or more.

\section{Research Method}

This research was conducted using empirical juridical research methods. The empirical juridical research method is an approach by looking at the legal reality that occurs in society. And this is an empirical phenomenon that occurs in society. Conceptualized by empirical phenomena observed in the realm of experience, law is no longer interpreted as a normative rule, whose existence is exclusively in a formal legitimacy system. From the aspect of its substance, law is now more visible as a social unit whose form is empirical. ${ }^{5}$

${ }^{4}$ Sjaifurrachman dan Habib Adjie,2011, Aspek Pertanggungjawaban Notaris dalam Pembuatan Akta, CV. Mandar Maju, Bandung, pg. 5 .

${ }^{5}$ Bambang Sunggono, Metode Penelitian Hukum, Raja Grafindo Persada, Jakarta, 2001. pg.78. 


\section{Discussion}

\section{Legal Consequences of a Notary Committing a Criminal Act that has Permanent Legal Force}

In addition to the above actions, Notaries can also commit criminal acts of corruption as has been tried in the Class IA Padang District Court Decision Number 27/Pid.Sus/TPK/2016/PN-Pdg. In this case, the Notary is accused of corruption in land acquisition for Campus III of the State Islamic Institute (IAIN) Imam Bonjol Padang (now UIN Imam Bonjol). When there are problems in land acquisition that are directly related to criminal law, even though the scale is small, criminal law does not see it that way, if there is an alleged violation of criminal law. Notaries will be very difficult if the aspects of criminal law state that there are allegations of corruption in carrying out their duties and authorities or from the deed they made.

Based on an interview with Ibuk Siska who explained that the Regional Supervisory Council (MPD) knew about the alleged corruption case committed by a Notary in Padang City from the mass media and immediately followed up the search for information related to the news. After obtaining evidence and information regarding the determination of the Notary as a suspect by the Police, the Notary has been detained, so that he cannot carry out his duties and authorities. Because he is undergoing the detention period, the Notary is temporarily suspended from his position as described in Article 9 paragraph (1) letter e of the UUJN-P and Article 66 of the Regulation of the Minister of Law and Human Rights Number 25 of 2014. The dismissal is proposed in stages by the MPD to MPW, MPW to the MPP, MPP to the Minister, because the Minister who has the authority to impose a temporary suspension is the Minister at the suggestion of the MPP. (Article 9 paragraph [3] UUJN-P).

However, the author finds confusion about who has the right to temporarily suspend, namely between the provisions of Article 9 and Article 77 of the UUJN-P. In Article 9 paragraph (3) of the UUJN$\mathrm{P}$ it is stated that the temporary dismissal of a Notary as referred to in paragraph (2) is carried out by the Minister at the suggestion of the Central Supervisory Council, while Article 77 letter $\mathrm{c}$ of the UUJN states that the Central Supervisory Council has the authority to impose a temporary suspension. Of the two provisions, who can impose a temporary suspension. Is it the Minister or MPP? However, the author is of the opinion that the Minister who has the authority to temporarily suspend him, while the MPP is limited to making suggestions to the Minister. ${ }^{6}$

However, the author finds confusion about who has the right to temporarily suspend, namely between the provisions of Article 9 and Article 77 of the UUJN-P. In Article 9 paragraph (3) of the UUJN$\mathrm{P}$ it is stated that the temporary dismissal of a Notary as referred to in paragraph (2) is carried out by the Minister at the suggestion of the Central Supervisory Council, while Article 77 letter $\mathrm{c}$ of the UUJN states that the Central Supervisory Council has the authority to impose a temporary suspension. Of the two provisions, who can impose a temporary suspension. Is it the Minister or MPP? However, the author is of the opinion that the Minister who has the authority to temporarily suspend him, while the MPP is limited to making suggestions to the Minister.

This temporary suspension is intended to anticipate the practice that has occurred so far in the case of a Notary who is undergoing a legal process but continues to carry out his position. MPD prepares and submits a report related to the case to MPW. The MPW then examines the report from the MPD and submits it to the MPP. Then the MPP examines the MPW report and makes a decision to propose to the Minister that the Notary be given a temporary suspension.

With the absence of criminal sanctions in the UUJN, the regulation regarding sanctions against Notaries is less than perfect. It is important to include criminal sanctions in the UUJN in addition to making

${ }^{6}$ Interview with Ms. Siska as a Member of the Padang Notary Area Supervisory Board, on Wednesday, June 16, 2021 
them a corridor in carrying out their authority, criminal sanctions are also preventive in nature before a crime occurs. Criminal sanctions in the UUJN are also very important so that the law is effective and can enforce justice and provide legal certainty for people who are harmed as a result of authentic deeds made by a Notary. If it is associated with the theory of legal certainty.

Based on the explanation above, the authors conclude that with the dismissal of a Notary who commits a criminal act that has permanent legal force, the legal consequences that arise are if the criminal threat is less than 5 (five) years, the Notary is temporarily dismissed from his position and pays all losses that arise from the temporary suspension. If the penalty is 5 (five) years or more, the Notary is dishonorably dismissed and all authorities attached to the Notary's position are revoked in carrying out his duties as a public official. In other words, the Notary can no longer carry out his authority and obligations as stated in Article 15 - Article 16 of the UUJN-P. The notary is also required to pay compensation to the parties who feel that their rights have been harmed by the dismissal of the notary. In addition, the SABU and SABH Notary System accounts were blocked at the Ministry of Law and Human Rights.

A Notary must always improve his potential in carrying out his duties and positions such as always following legal developments in the notary world from day to day, participating in educational activities, seminars and training held by organizations or related to the world of notary so as to create professionalism in carrying out a duties and positions. In addition, a Notary before making a deed for the parties requires an attitude of confidence, comfort, caution and in accordance with the rules because the subject facing the Notary and the object that becomes the substance to be stated in the deed is a single entity, so for this the Notary must at least know how is the condition of the subject and the position of the object, because everyone who comes to a notary has different interests, aims and objectives for that it is necessary to protect himself from a notary in issuing a deed to the parties. ${ }^{7}$

\section{Implications of Dismissal of a Notary Who Commits a Criminal Act that has Permanent Legal Force against the Notary Protocol}

Regarding the dishonorable dismissal of a Notary as referred to in Article 13 of the UUJN-P, the submission of the Notary Protocol is carried out by a Notary to another Notary appointed by the Minister on the recommendation of the MPD (Article 63 paragraph (4) UUJN-P). If the notary protocol is not submitted within 30 (thirty) days, then the MPD is authorized to take the notary protocol (Article 63 paragraph (6) UUJN-P). Article 70 Regulation of the Minister of Law and Human Rights Number 25 of 2014 concerning Terms and Procedures for Appointment, Transfer, Dismissal and Extension of the Term of Office of a Notary, regarding the dishonorable dismissal of a Notary for committing a crime punishable by imprisonment of 5 (five) years or more, then the MPP will propose another Notary as the holder of the Notary Protocol to the Minister within a period of no later than 30 (Thirty) days from the date the Court's decision has permanent legal force.

Since the minutes of the submission of the Notary protocol to another Notary as the holder of the protocol are made, the responsibility for maintaining and storing the Notary protocol is transferred to the Notary who receives the protocol. The notary who was dismissed related to the crime he had committed had legal force and remained only responsible for the contents of the deed he made, because this is a personal responsibility according to Ms. Markhalina. ${ }^{8}$

In practice, the handover of the notary protocol cannot be carried out according to the time period determined by the law, this is because the tiered approval process from MPD to MPW, MPW to MPP and MPP to the Minister takes a long time so that the handover process does not running as it should. This creates legal uncertainty regarding the maintenance of the protocol of the convicted notary. Who is

\footnotetext{
${ }^{7}$ Interview with Mr. Muhamad Ishaq, Notary in Padang City, on Thursday, March 18, 2021

${ }^{8}$ Interview with Notary Markhalina Satrianita, as a Former Supervisory Board for the West Sumatra Region, on Friday, April 09, 2021
} 
responsible for maintaining the state archives? The authority of the MPD and the Substitute Notary Public in maintaining the Notary Protocol arises after a temporary suspension and the authority of the Notary receiving the Protocol appears after the dishonorable dismissal. The government must immediately find a solution or legal breakthrough to the problems that arise in the application of the rules of this Law so that the public can obtain legal certainty about the deed that is part of the Notary Protocol. The legal vacuum regarding the maintenance of the Notary Protocol which is the state archive is a problem that must be resolved together.

A Notary in carrying out his duties and positions in making an authentic deed must always comply with the rules contained in the UUJN-P and the Notary Code of Ethics and other laws and regulations related to the deed made, but if the Notary in carrying out the work is not in accordance with the has been regulated, then the Notary indirectly does not try to protect himself which leads to sanctions that will be received by the Notary both civil and criminal.

\section{Conclusion}

1. The legal consequences of a Notary who commits a criminal act that has permanent legal force is that the Notary is temporarily dismissed if the criminal penalty is less than 5 (Five) Years and dishonorable dismissal of the Notary whose penalty is 5 (Five) Years or more. The notary is also required to pay for any losses arising from the temporary or dishonorable dismissal.

2. Notaries who are dishonorably dismissed will be blocked from the Business Entity Administration System (SABU) and Legal Entity Administration System (SABH) accounts at the Ministry of Law and Human Rights.

3. Dismissal of a Notary who commits a criminal act that has permanent legal force, will have an impact on the Protocol owned by the Notary. Since the determination of the status of the suspect against the Notary and the detention, then in stages from MPD to MPW and MPW to MPP to propose the temporary dismissal of the Notary to the Minister. After the criminal act committed by the Notary has permanent legal force, the MPW will propose the dismissal of the Notary with disrespect to the MPP and the Dismissal of the Notary shall be carried out by the Minister at the suggestion of the MPP. After the Notary is dismissed from his position, the Minister will appoint a Notary who will receive the Notary Protocol from the Notary who was dishonorably dismissed on the recommendation of the MPD.

\section{Suggestion}

1. It is recommended that a Notary should uphold the dignity of the position of a Notary by carrying out his/her position in a trustworthy, honest, thorough, independent and impartial manner as stated in the Notary's oath of office.

2. It is suggested to the Notary that he should be more careful, thorough and thorough in applying the legal rules that will be set forth in the deed and always be aware of the legal consequences arising from every deed he makes because the notary deed is an authentic deed that has perfect evidentiary power.

3. It is recommended that a legal breakthrough be made to address the legal vacuum related to the temporary dismissal process of a notary that is more than 6 (six) months and also for dishonorable discharge, which process requires the approval of the Minister and takes a long time. 


\section{Reference}

Bambang Sunggono, Metode Penelitian Hukum, Raja Grafindo Persada, Jakarta, 2001

Mochtar Kusumaatmadja, B. Arief Sidharta, Pengantar Ilmu Hukum Suatu Pengenalan Pertama Ruang Lingkup Berlakunya Ilmu Hukum Buku I, Bandung: Alumni, 2000

Herlien Budiono, 2014, Ajaran Umum Hukum Perjanjian dan Penerapannya di Bidang Kenotariatan, PT. Citra Aditya Bakti, Bandung.

Interview with Ms. Siska as a Member of the Padang Notary Area Supervisory Board, on Wednesday, June 16,2021

Interview with Mr. Muhamad Ishaq, Notary in Padang City, on Thursday, March 18, 2021

Interview with Notary Markhalina Satrianita, as a Former Supervisory Board for the West Sumatra Region, on Friday, April 09, 2021

Sjaifurrachman dan Habib Adjie, 2011, Aspek Pertanggungjawaban Notaris dalam Pembuatan Akta, CV. Mandar Maju, Bandung.

Sudikno Mertokusumo, 2003, Mengenal Hukum Suatu Pengantar, Liberty, Yogyakarta.

Supriadi, 2008, Etika \& Tanggung Jawab Profesi Hukum di Indonesia, Sinar Grafika, Jakarta.

\section{Copyrights}

Copyright for this article is retained by the author(s), with first publication rights granted to the journal.

This is an open-access article distributed under the terms and conditions of the Creative Commons Attribution license (http://creativecommons.org/licenses/by/4.0/). 